\title{
12. Türkçenin yabancı dil olarak öğretiminde uzaktan eğitime yönelik öğrenci görüşleri
}

Halit KARATAY

Seda KAYA²

Derya BAŞER3

APA: Karatay, H.; Kaya, S.; Başer, D. (2021). Türkçenin yabancı dil olarak öğretiminde uzaktan eğitime yönelik öğrenci görüşleri. RumeliDE Dil ve Edebiyat Araştırmaları Dergisi, (24), 223-232. DOI: $10.29000 /$ rumelide.995286.

$\ddot{O} \mathbf{z}$

Covid-19'un kapalı ortamlarda kısa sürede yayılması ve insanların sağlığını tehdit etmesi sokağa çıkma kısıtlamalarına ve sağlık önlemlerinin alınmasına neden olmuştur. Bu önlemlerden biri de eğitim kurumlarının yüz yüze eğitim yerine uzaktan eğitime geçmeleridir. Uzaktan eğitime dâhil olan öğrencilerden bir kısmı Türkçeyi yabancı dil olarak öğrenen öğrencilerdir. Bu çalışmada 2020-2021 yılı bahar döneminde BAİBÜ TÖMER'de Türkçeyi yabancı dil olarak uzaktan eğitim yoluyla B1-B2 düzeyinde öğrenen 50 öğrencinin uzaktan eğitime yönelik görüşleri tespit edilmiştir. Öğrencilerin görüşleri iki sorudan oluşan yapılandırılmış görüşme formu ile alınmıştır. Öğrencilerin uzaktan eğitim ile ilgili görüşleri, ‘öğrencilerin uzaktan eğitimi tercih etme durumları, uzaktan eğitime yönelik olumlu ve olumsuz görüşleri’ olmak üzere üç ana temada toplanmıştır. Salgın döneminde 50 öğrenciden 12'si yüz yüze eğitim yerine uzaktan eğitimi tercih edeceğini belirtmiştir. Öğrenciler uzaktan eğitime yönelik olumlu görüş olarak: "Virüsten koruduğunu, zamandan tasarruf sağladığını, kaliteli eğitim verildiğini, dersi tekrar izleyebilme kolaylığı sağladığını, daha az yorucu olduğunu, alternatif bir öğrenme yolu olduğunu ve daha ucuz olduğunu” belirtmişlerdir. Olumsuz görüş olarak "iletişim ve etkileşim sorunlarını, öğretme yönünün zayıf olmasını, sosyalleşememeyi, internet ve uygulama sorunlarını, derslere az katılımın olmasını, konuşma ve yazma becerisinin yeterince gelişmemesini, derse odaklanma sorununu, derslerin sıkıcı olmasını, işbirlikli öğrenmeyi engellemesini, sağlı̆̆a zararlı olmasını, konuşma kaygısına sebep olmasını, pahalı olmasını ve sınavların yeterince güvenilir olmamasını göstermişlerdir.

Anahtar kelimeler: Covid-19, salgın, TYDÖ (Türkçenin yabancı dil olarak öğretimi), uzaktan eğitim, Türkçe hazırlık Eğitimi ABD (Bolu, Türkiye), halitkaratay@gmail.com, ORCID ID: 000o-0003-1820-0361 [Araștırma makalesi, Makale kayit tarihi: 17.08.2021-kabul tarihi: 20.09.2021; DOI: 10.29000/rumelide.995286

$2 \quad$ Arş. Gör., Bolu Abant İzzet Baysal Üniversitesi, Eğitim Fakültesi, Türkçe ve Sosyal Bilimler Eğitimi Bölümü, Türkçe Eğitimi ABD (Bolu, Türkiye), sedakayabp@gmail.com, ORCID ID: 000o-0002-4658-4924

Arş. Gör. Dr., Bolu Abant İzzet Baysal Üniversitesi, Eğitim Fakültesi, Bilgisayar ve Öğretim Teknolojileri Eğitimi Bölümü, Bilgisayar ve Öğretim Teknolojileri ABD (Bolu, Türkiye), derya.yasar@gmail.com, ORCID ID: 00oo-o002-2006-8737

Adres $\mid$ Address

RumeliDE Dil ve Edebiyat Araştırmalar Dergisi Osmanağa Mahallesi, Mürver Çiçeği Sokak, No:14/8 Kadıköy - ISTANBUL / TÜRKIYE 34714 e-posta: editor@rumelide.com

RumeliDE Journal of Language and Literature Studies Osmanağa Mahallesi, Mürver Çiçeği Sokak, No:14/8

Kadıköy - ISTANBUL / TURKEY 34714 tel: +90 $5057958124,+902167730616$

e-mail: editor@rumelide.com

phone: +90 5057958124 , +90 2167730616 


\title{
Student views on distance education in teaching Turkish as a foreign language
}

\begin{abstract}
The spread of the Covid-19 virus especially in closed environments, in a short time and threatening people's health caused curfews and health measures to be taken. One of these measures is the transition of educational institutions to distance education instead of face-to-face education. In this study, it is aimed to determine the views of 50 students who learned Turkish as a foreign language at B1-B2 level through distance education at BAIBU TÖMER in the spring semester of 2020-2021. The opinions of the students were taken with a structured interview form consisting of two questions. The students' opinions about distance education were gathered under three main themes: "the students' preference for distance education, their positive and negative opinions about distance education". According to the results, 12 students would prefer distance education. Among the positive opinions about distance education, the students stated that it protects against viruses, saves time, provides qualified education, ease rewatching the lesson, is less tiring, is an alternative method and is cheaper. Negatively, they stated that there are communication and interaction problems; it hinders socializing, there are internet and application problems, it causes low participation in classes, it does not support speaking and writing skills of students adequately, problem of focusing on the lesson arises, lessons are boring, it hinders collaborative learning, it is unhealthy, it causes speaking anxiety, it is expensive and the exams are not sufficiently reliable.
\end{abstract}

Keywords: Covid-19, distance education, pandemic, TTFL (teaching Turkish as a foreign language), Turkish preperatory

\section{Giriş}

2019 yılında ortaya çıkan COVID-19 virüsü bütün dünyayı etkilemiştir. Bu virüs sadece insanların sağlığını, ekonomilerini ve yaşam biçimlerini etkilememiş aynı zamanda virüsün yol açtığı salgın eğitim sistemini de etkilemiştir. Virüsün kısa sürede ve hızla yayılıyor olması ayrıca ölümcül vakaların da tespit edilmesi nedeniyle ülkeler sokağa çıma kısıtlamaları, maske takma zorunluluğu, sosyal mesafe kuralı, seyahat kısıtlamaları gibi bir dizi kural belirlemiştir. Virüsün sadece yüzeylerden değil hava yolu ile de bulaşması nedeniyle tüm dünyada yüz-yüze eğitimin yerini kısmi ya da tamamen uzaktan eğitim almıştır.

Uzaktan eğitim, farklı mekânlarda bulunan öğretici ve öğrencilerin birbirleriyle ve ders materyalleri ile etkileşimlerini sağlayabilmek amacıyla telekomünikasyon sistemlerinin kullanıldığ kurum tabanlı sunulan örgün bir eğitimdir (Schlosser \& Simonson, 2009). Doğası gereği uzaktan eğitim öğrencilere ve öğreticilere zaman ve mekân bağımsızlığı, ekonomiklik, evden çıkmak zorunda olmadan eğitimin sürdürülebilirliği, öğrenme sürecinde esneklik, zamandan tasarruf, işe devam edebilme olanağı (Sadeghi, 2019), firsat eşitliği, öğrenmenin bireyselleşebilmesi, küresel öğrenme ortamları, yeni konulara yönelik eğitim alabilme, yeni teknolojilerden ve yöntemlerden yararlanabilme (Gürer, 2021) gibi pek çok fayda sağlamaktadır. Öte yandan, uzaktan eğitim olası dikkat dağınıklığının üstesinden gelme, teknolojiden kaynaklanabilecek sorunları giderme, fiziksel etkileşimin olamaması, öğreticilerle iletişimde kalabilmenin zorluğu (Sadeghi, 2019), zaman yönetiminde yaşanılan zorluklar, uygulamalı dersler için yeterince verimli olmayan öğrenme ortamları, öğrencilere her zaman anında geri bildirim sağlayamama, sınırlı iletişim, teknik sorunlar ve öğreticinin uzaktan eğitim ortamlarındaki

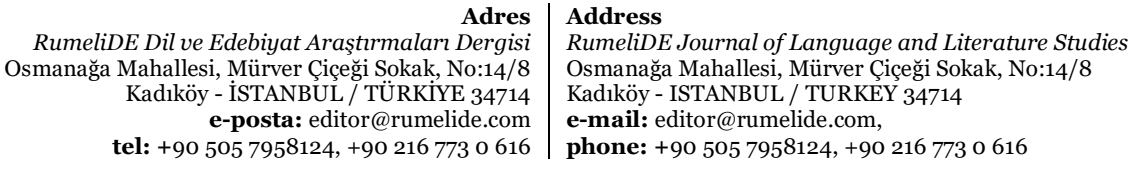

RumeliDE Journal of Language and Literature Studies

Osmanağa Mahallesi, Mürver Çiçeği Sokak, No:14/8

Kadıköy - ISTANBUL / TURKEY 34714

e-mail: editor@rumelide.com,

phone: +90 505 7958124, +90 2167730616 
deneyimsizliğinden kaynaklanabilecek verimsiz öğrenme deneyimleri (Gürer, 2021) gibi dezavantajları da beraberinde getirmektedir.

Salgın sürecinde uzaktan eğitime sadece ilköğretim, lise ve üniversite öğrencileri değil aynı zamanda Türkçeyi yabancı dil olarak öğrenen yabancı öğrenciler de dâhil edilmiştir. Son yıllarda, Türkiye'deki üniversitelerde öğrenim gören uluslararası öğrenci sayıları büyük artış göstermiştir. Uluslararası öğrencilerin sayısı 2010 yılında 4,5 milyon iken günümüzde 7,5 milyona ulaşmış ve ilerleyen yllarda da hızla artması beklenmektedir (Yurtdışı Türkler ve Akraba Topluluklar Başkanlığı, 2021). Sayları her geçen gün artan yabancı öğrencilerin Türkiye'deki eğitime ya da yaşama uyum sağlayabilmeleri için Türkçenin yabancı dil olarak öğretimine gereken önemin verilmesi gerekmektedir. Bu yüzden eğitimi verecek olan öğretmenlerin de donanımlarının artırılması gerekmektedir. Çetin (2020) öğreticilere verilen sertifika eğitimlerinin niteliğinin artırılması ve standart bir eğitim verilebilmesi için uzaktan eğitim ile yüz yüze eğitimin harmanlanmasını önermektedir. Öğrenciler için de daha verimli ve eşgüdümlü bir eğitim sunulabilmesi için aynı öneri sunulabilir.

Uzaktan eğitim yoluyla Türkçeyi yabancı dil olarak deneyimleyen 4 öğretim elemanı ve 8 öğrenci ile yapılan görüşme sonuçlarına göre katılımcıların uzaktan eğitimde iletişim, mekân bağımsızlı̆̆ı ve ekonomik açıdan başarılı bulundukları, konuşma ve yazma becerilerinin geliştirilmesi konusunda uygulama yetersizliğinden ve materyal eksikliğinden kaynaklanan sorunlar yaşadıkları belirtilmiştir (İskender, 2021). Ayrıca çalışmada, dilbilgisinin de yeterince verimli işlenemediği ve teknik sorunların uzaktan eğitime uyum sürecini olumsuz etkilediği vurgulanmıştır. Özer ve Çekici (2020)'nin çalışmasında da öğreticiler, uzaktan eğitimin öğrencilerin anlatma becerilerini geliştirmediğini belirtmişlerdir. Güngör, Çangal ve Demir (2020) çalışmalarında, öğrencilerin yüz yüze eğitimi uzaktan eğitime tercih ettikleri, mekân ve zaman bağımsızlı̆̆ ile ilgili olumlu görüşlere sahip olsalar da uzaktan eğitimde etkileşim, dil becerilerinin gelişimi, alt yapı ve ödev kontrolü ile ilgili sorunlar yaşandığı sonucuna varmışlardır.

Türkçeyi yabancı dil olarak öğrenenlerin yaşadıkları bu deneyimin iyi bir şekilde irdelenmesi, salgın sonrasında yüz yüze verilecek bu eğitimlerin uzaktan eğitim ile desteklenmesi ya da tamamen uzaktan eğitim yoluyla verilmesi durumunda daha verimli öğrenme ortamları sunmak açısından önemlidir. Bu çalışmada, Türkçe hazırlık kursunu uzaktan eğitim yoluyla alan öğrencilerin uzaktan eğitime yönelik olumlu ve olumsuz görüşlerinin araştırılması amaçlanmaktadır. Araştırma sonuçlarının, Türkçe hazırlık kursları kapsamında gelecekte sunulabilecek uzaktan eğitim uygulamalarının tasarımına ışı tutması beklenmektedir. Böylece, uzaktan eğitimin yukarıda bahsedilen yararları artırılıp olumsuzlukları en aza indirilerek öğrencilere daha verimli bir ortam sunulması sağlanabilecektir. Bu amaçla çalışmada aşağıdaki soruya yanıt aranmıştır:

1. Türkçeyi yabancı dil olarak öğrenen öğrencilerin uzaktan eğitime yönelik görüşleri nelerdir?

\section{Araştırmanın yöntemi}

Çalışmaya veri toplamak amacıyla doküman inceleme tekniğine başvurulmuştur. Doküman incelemesinde, çalışılacak konulara dair yazılı ve basılı belgelerin analizi yapılır (Yıldırım ve Şimşek 2008).

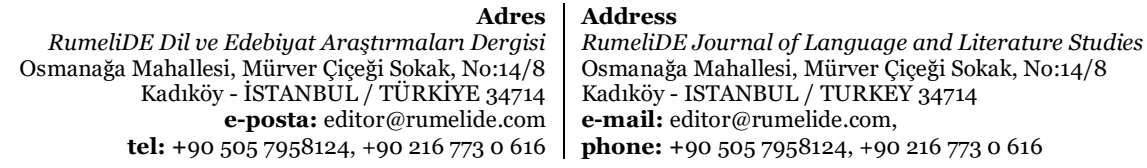




\section{Çalışma grubu}

Çalışma grubu, 2020-2021 yılı bahar döneminde Bolu Abant İzzet Baysal Üniversitesi TÖMER (Türkçe Öğretimi Uygulama ve Araştırma Merkezi)'de Türkçeyi yabancı dil olarak öğrenen 50 bağımsız düzey (B1-B2) öğrenciden oluşmaktadır. 20-29 yaş aralığında olan öğrencilerin 15’i kadın; 35’i ise erkektir. Öğrencilerin 17'si Türk soylu iken 33’ü Arap’tır.

\section{Veri toplama aracı}

Çalışmanın başlangıcında üç uzman görüşüne başvurularak UEÖGF (uzaktan eğitim öğrenci görüşleri formu) oluşturulmuştur. Bu form oluşturulurken öğrencilerin bulundukları dil düzeyleri (B1-B2) ve soruların anlaşlabilirliği dikkate alınmıştır. Görüşme formundaki sorulardan biri çoktan seçmeli iken diğeri açı uçludur. Formda öğrencilerin cinsiyet ve uyruklarını yazmaları istenmiştir. Demografik bilgilerden sonra öğrencilere ilk olarak "Tercih hakkı sunulsa uzaktan mı yüz yüze eğitimi mi tercih ederdiniz” diye sorulmuştur. Ayrıca, deneyimlerine dayanarak uzaktan eğitime yönelik olumlu ve olumsuz görüşlerini yazmaları istenmiştir.

\section{Veri toplama süreci}

UEÖGF'deki veriler uzaktan eğitimi tercih etme durumu, uzaktan eğitimle alakalı olumlu ve olumsuz görüşler şeklinde ana başlıklara ayrılmıştır. Bu ana başlıklar ile ilgili iki sorudan oluşan bir anket Google Formlar’a yüklenmiş ve öğrencilere doldurmaları için gönderilmiş̧ir.

\section{Verilerin incelenmesi}

Verilerin içerik incelemesi yapılmıştır. İlk olarak UEÖGF ile alınan uzaktan eğitimle alakalı B1-B2 düzeyi öğrencilerinin olumlu ve olumsuz görüşleri tek bir dosya olarak MAXQDA nitel analiz programına yüklenmiştir. Veriler 'uzaktan eğitimi tercih etme durumu', 'uzaktan eğitimle alakalı olumlu görüşler, uzaktan eğitimle alakalı olumsuz görüşler' olmak üzere toplam 3 ana başlık altında incelenmiştir. Görüşler ilgili ana temalar altında kodlandıktan sonra her ana başlı̆̆ın altına alt temalar oluşturularak olumlu ve olumsuz görüşler kendi içinde ayrılmıştır. Bu görüşler daha sonra üç alan uzmanı tarafından iki kez okunarak kendi içinde ana ve alt temalar sağlamlaştırılmıştır. Bu işlem bittikten sonra uzmanlar tarafından yapılan kodlamaların güvenilirliği ve tutarlılı̆̆ı tekrar gözden geçirilmiş ve bulguların son şekline karar verilmiştir.

\section{Bulgular}

Bu bölümde Türkçeyi yabancı dil olarak öğrenen B1 ve B2 düzey öğrencilerinin uzaktan eğitime dair görüşlerine yer verilmiştir.

1. Eğitim biçimi: “Tercih hakkı sunulsa uzaktan mı yüz yüze eğitimi mi tercih ederdiniz?" sorusuna 12 öğrenci uzaktan eğitimi, 38 öğrenci ise yüz yüze eğitimi tercih ederiz diye cevap vermiştir. Bununla ilgili olumlu ve olumsuz görüş bildiren öğrencilerin gerekçeleri 2 ve 3 numaralı başlıklarda verilmiştir:

2. Uzaktan eğitimin olumlu yönleri: “Uzaktan eğitimin olumlu ve olumsuz yönleri nelerdir?” öğrencilere yöneltilen diğer bir sorudur. Öğrencilerin uzaktan eğitime ilişkin olumlu görüşleri aşağıda verilmiştir.

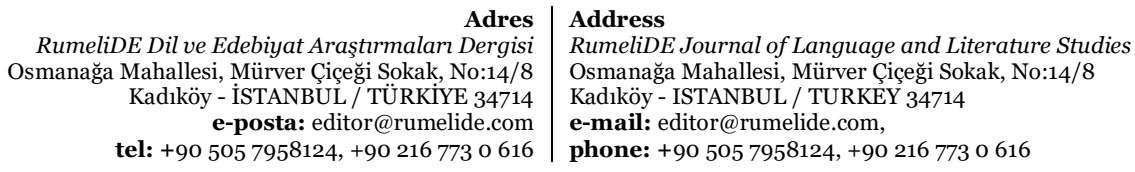


2.1. Sağlığı koruma: Araştırmaya katılan 8 öğrenci C19 döneminde sağlıklarını korumak için, bu dönemde uzaktan eğitimin daha iyi ve güvenilir olduğunu söylemiştir. "Dışarıda virüsten korkuyoruz ama uzaktan eğitimde virüsten uzak kalabiliyoruz k22.”

2.2. Zamandan tasarruf: Araştırmaya katılan 5 öğrenci uzaktan eğitimin yüz yüze eğitime göre zamandan tasarruf sağladığını; yüz yüze eğitimde okula gelmek için harcadıkları zamanın kendilerine kaldığını belirtmiştir. "Normalde bir iki saat yolda geçiyor. Zamandan tasarruf ediyorum k13."

2.3. Eğitimin niteliği: 5 öğrenci, uzaktan eğitimin yüz yüze eğitime göre daha nitelikli olduğunu belirtmiştir. "Dersler kaliteli k41."

2.4. Dersi tekrar etme: 3 öğrenci katılamadıkları dersi daha sonra tekrar izleyebildiklerini, yüz yüze eğitimde bu olanağın olmadığını belirtmiştir. "Dersi tekrar izleme şansım var k43." Uzaktan eğitimde dersler kaydedildiği için öğrenciler derse katılmasalar bile daha sonra ders kayıtlarından istedikleri zaman dersi izleyebilmektedirler.

2.5.Daha az emek: 2 öğrenci ders süresince evde oturdukları için daha az yorulduklarını belirtmiştir. “Hareket etmemize gerek yok. Daha az yoruluyoruz k9.” Yüz yüze eğitimde öğrencilerin okula gelmesi, derste öğretim etkinliklerine katılması gerekir. Bu onların bir hayli emek harcamalarını gerektirdiği için yorulmalarına neden olmaktadır. Uzaktan eğitimde, evde oturarak veya uzanarak dersi izleyebilmektedirler. Bu da onların daha az yorulmalarını sağlamaktadır.

2.6. Öğrenme yolu: 1 öğrenci uzaktan eğitimin yüz yüze eğitim yerine kullanılabilecek alternatif bir yol olduğunu belirtmiştir. Uzaktan eğitim, yüz yüze eğitimin yerine kullanılabilecek bir öğrenme yoludur. Yüz yüze eğitimin mümkün olmadığı durumlarda öğrenme ihtiyacını karşılayabilecek bir yoldur. "Alternatif bir teknik k17."

2.7. Ekonomiklik: 1 öğrenci, uzaktan eğitimin yüz yüze eğitime göre maliyet açısından daha ucuz olduğunu belirtmiştir. Okula gelmek için harcanacak paranın kendilerine kaldığını düşünmektedir. "Uzaktan eğitim ucuz k33."

3. Uzaktan eğitimin olumsuz yönleri: Öğrencilerin uzaktan eğitime ilişkin olumsuz görüşleri aşağıda verilmiştir.

3.1. İletişim sorunları: Öğrencilerin 16'sı uzaktan eğitimde birbirleri ve öğretmen ile yeteri kadar iletişim kuramadıklarını belirtmiştir. "Uzaktan eğitimde öğrenci ve öğretmen birbirini anlayamıor. Uzaktan eğitimde sağlikh iletişim kurmak zor k25." Uzaktan eğitimde yaşanan internet ve elektrik kesintileri, mikrofonun ve kameranın olmaması ya da zaman zaman çalışmaması, kullanılan jest ve mimiklerin sınırlı olması öğretmen ve öğrenci arasında etkili iletişimi engelleyebilmektedir.

3.2. Eğitimin niteliği: Öğrencilerin 16'sı uzaktan eğitimde öğretmenin yaptığı açılamaların yeterli olmadığını bu yüzden de dersi yeteri kadar anlayamadıklarını belirtmiştir. "Bence uzaktan yapılan eğitim yani internet üzerinden yapılan açıklamalar çok iyi değil diye sanıyorum k31.” Uzaktan eğitimde yapılan etkinlikler yüz yüze eğitimde yapılanlara göre sınırlı kalmaktadır. Ayrıca derslerde öğrencilere verilen dönüt ve düzeltmeler, yazma çalışmaları ve ödevler zamanında yapılmamaktadır. Bu da doğrudan eğitimin niteliğini etkilemektedir. "Yüz yüze eğitimde daha çok etkinlik yapıyoruz. Ödevleri daha zamaninda yapıyoruz k6."

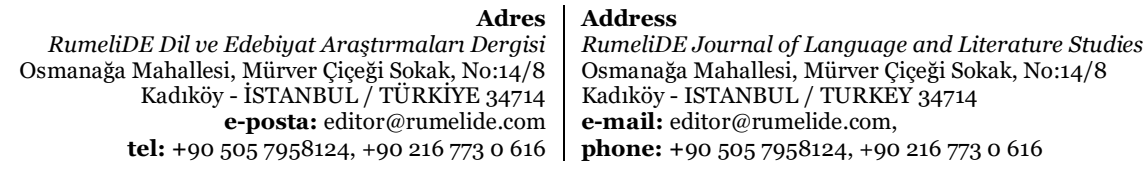


3.3. Sosyalleşme: 13 öğrenci, uzaktan eğitimde arkadaşları ile yüz yüze görüşemedikleri için birlikte bir etkinlik yapamadıklarını, bu yüzden sosyalleşemediklerini, birbirlerini iyice tanımadıkları için iletişim kuramadıklarını belirtmiştir "Uzaktan eğitimde sosyalleşme yok. Arkadaşlarım olsa onlarla bir şeyler yapabiliriz k11."

3.4. İnternet ve uzaktan eğitim araçları sorunları: 13 öğrenci, uzaktan eğitimde nitelikli internet bağlantısının olmayışı, elektrik kesintileri, kullanışlı öğretim uygulamaları ve araçlarının yetersizliği nedeniyle öğrenmenin niteliğinin düştüğünü belirtmiştir. "İnternet ve elektrik kesintisi oluyor. Teknik sorunlar oluyor. Mesela bazen link çalşmıyor ya da öğretmenin mikrofonu çalş̧mıyor kg.”

3.5. Derslere etkin katılım: Öğrencilerin 7’si uzaktan eğitimde öğrencilerin hepsinin aynı anda derse ve etkinliklere katılmadığını, uygulamayı açıp öğretmenin sorduğu sorulara ve etkinliklere aynı anda dönüt vermediğini, sadece yoklama için uygulamayı açtığını daha sonra başka işlerle ilgilendiğini belirtmiş̧ir. Bu durum dersin işlenişini olumsuz etkilemektedir. "Öğrencilerin bir kısmı sınıfta uyuyor bir kısım da dersi açıp diğer işlerini yapıyor k47."

3.6. Anlatma becerileri: Öğrencilerin 10 'u anlatma becerileri olan konuşma ve yazmanın uzaktan eğitimde yeteri kadar gelişmediğini belirtmiştir. Çünkü uzaktan eğitimde öğrenciler derslere etkin katılmadığı için onları konuşturmak, sesletim hatalarını düzeltmek veya yazılarını anında görüp dönüt vermek zordur. Ĕ̆itim yüz yüze olmadığı için onlara konuşurken yardımcı olup kaygılarını gidermek de kolay değildir. "Konuşma kaygım var. Öğretmene soru soramıyorum k4", "Konuşma becerimizi geliştiremiyoruz k4o.", "Yazma becerimiz az gelişiyor k7." Uzaktan eğitimde konuşma ve yazma becerilerinin geliştirilmesi için öğrencilere rehberlik etmek, edimleri ile ilgili dönüt vermek ve düzeltme yapmak zor olduğu için öğrencilerin bu becerileri daha az gelişmektedir.

3.7. Öğrenme isteği: Öğrencilerin 8’i uzaktan eğitimde derslere odaklanamadıklarını ve sıkıldıklarını belirtmişlerdir. Bu yüzden de derslerin sıkıcı olduğunu düşünmektedirler. "Derslere odaklanamıyoruz k4o"; "Dersler sıkıcı k4."

3.8. İşbirlikli öğrenme: 3 öğrenci, uzaktan eğitimin işbirlikli öğrenmeye engel olduğunu belirtmiştir. Öğrencilerin öğrenmelerinde sadece öğretmenin değil birbirlerinin de etkisi vardır. Özellikle yüz yüze yapılan grup çalışmalarında öğrenciler bilmedikleri konuları birbirine sorarak öğrenebilmektedirler. Uzaktan eğitimde grup çalışmalarının sınırlı kalması ve herkesin derse etkin katılmaması işbirlikli öğrenmeyi engellemektedir. "Arkadaşlarım olsa onlarla bir şeyler yapabiliriz işbirlikli, sosyal öğrenme yok k11.", “Uzaktan eğitimde birbirimizden öğrenemeyiz k8."

3.9. Sağlı̆̆ koruma: Öğrencilerin 3 'ü uzaktan eğitimin sağlıklarını olumsuz etkilediğini belirtmiştir. Uzaktan eğitimde öğrencilerin ders boyunca bilgisayarın karşısında oturmaları gerekmektedir. Uzun süreli sabit oturma, ekrana bakma ve internete bağlı teknolojik bir araç kullanma sırt ağrısı, gözlerin yorulması ve radyasyondan zarar görme gibi sorunlara neden olmaktadır. "Radyasyona maruz kahıoruz k7.", "Sürekli bilgisayar başında durmak sağlĭ̆ımızı etkiliyor. Strtımız ağrıyor k8.”, "Işık gözümüzü yoruyor k9.”

3.10. Ekonomiklik: Bir öğrenci uzaktan eğitimin pahalı olduğunu belirtmiştir. Uzaktan eğitimde öğrencilerin akıllı telefon, internet, tablet ya da bilgisayara sahip olmaları gerekmektedir. Çoğu öğrencide akıllı telefon bulunsa da uzaktan eğitimi verimli bir şekilde alabilecekleri nitelikte değildir. Çoğunun bilgisayarı da yoktur. Ayrıca derslere internet bağlantısından kopmadan ve devamlı olarak

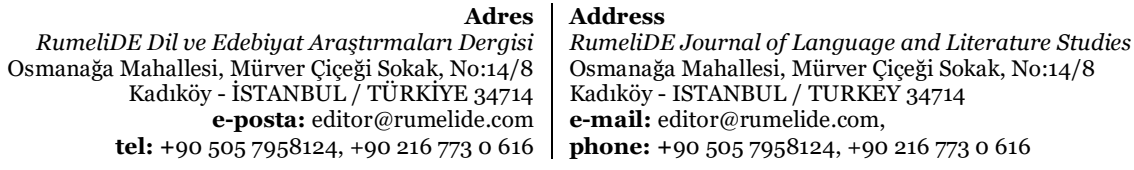


girebilmeleri için sınırsız internet bağlantısı gerekmektedir. Öğrencilerin bazıları ekonomik nedenlerden dolayı sınırlı kotaya sahip internet paketleri kullanmaktadırlar. Bu da eğitimin maliyetini artırmaktadır. "Pahah, internet, telefon ve bilgisayar lazım k1."

3.11. Sınavların güvenilirliği: Bir öğrenci uzaktan eğitimde sınavların güvenilir olmadığını belirtmiştir. Uzaktan eğitimde kamera açlk olsa bile öğrencilerin bulunduğu sınırlı bir alan görülebilmektedir ya da öğrencilerin kameralarının görüntü kalitesinin kötü olması öğrenci takibini zorlaştırmaktadır. Bu durumda sınavlarda kopya çekmenin önüne geçmek, uzaktan eğitimde yüz yüze eğitime göre daha zordur. "Sinavlarda kopya çekiliyor k4."

\section{Tartışma ve sonuç}

Covid19 virüsü nedeniyle yüz yüze yapılamayan eğitimler uzaktan eğitim yolu ile verilmeye başlamıştır. Uzaktan eğitim alan öğrencilerden bir kısmı da Türkçeyi yabancı dil olarak öğrenen öğrencilerdir. Öğrenciler eğitim aldıkları süre boyunca uzaktan eğitimin olumlu taraflarından yararlanmalarının yanında olumsuz yönleri ile de karşılaşmaktadırlar. Uzaktan eğitime yönelik Türkçeyi yabancı dil olarak öğrenenlerin görüşlerinin alındığı çalışmalarda öğrencilerin çoğunlukla uzaktan eğitimi değil, yüz yüze eğitimi tercih ettikleri söylenebilir (Güngör vd., 2020; Özer \& Çekici, 2020). Var olan çalışmalarda bu çalışma ile benzer sonuçlara ulaşılmıştır. BAİBÜ TÖMER'de Türkçeyi yabancı dil olarak öğrenen B1 ve B2 düzey öğrencilerinin uzaktan eğitime yönelik görüşlerinin incelendiği bu çalışmada da 50 öğrenciden sadece 12'si uzaktan eğitimi yüz yüze eğitime tercih ettiklerini belirtmişlerdir.

Öğrencilerin büyük bir kısmı yüz yüze eğitimi tercih ettiklerini belirtseler de uzaktan eğitime yönelik olumlu görüşleri de bulunmaktadır. Türkçenin yabancı dil olarak öğretimi alanında 4 öğretim elemanı ve 8 öğrenci ile yapılan çalışmada, İskender (2021) uzaktan eğitimin iletişimsel, mekânsal ve ekonomik açıdan olumlu yönlerinin bulunduğu sonucuna ulaşmıştır. Güngör vd., (2020), Özer ve Çekici (2020) ve Ustabulut (2021) mekândan bağımsız olunabilmesine ek olarak uzaktan eğitimin zaman özgürlüğü de sunduğunu belirtmişlerdir. Çünkü uzaktan eğitimde öğrenciler derse katılamadıkları durumlarda ders kaydını daha sonra izleyebilmektedir. Uzaktan dersler, hem eş zamanlı hem de eş zamansız yapılabilmektedir. Yani öğretmen anlatacağı dersi kayda alıp bunu sisteme yükleyebilmekte öğrenciler istedikleri zaman izleyebilmektedirler. Bu da öğretmen ve öğrencilerin aynı zamanda derste bulunma zorunluluğunu ortadan kaldırabilmektedir. Bu çalışmada, öğrenciler uzaktan eğitimi zamansal, mekânsal ve ekonomik açıdan olumlu bulmalarına ek olarak, uzaktan eğitim sayesinde sağlıklarını koruyabildiklerini, zamandan tasarruf sağladıklarını, uzaktan eğitimin nitelikli eğitime olanak tanıdığını, dersleri istedikleri zaman tekrar izleyebilme firsatı sunduğunu, kendilerini fazla yormadan az emek harcayarak derse katılabildiklerini ve yüz yüze eğitimin kullanılamadığı durumlarda kullanılabilecek bir yol olduğunu belirtmişlerdir.

Alanyazın incelendiğinde, uzaktan eğitim yoluyla Türkçenin yabancı dil olarak öğrenimine yönelik olumlu görüşlerinin yanı sıra olumsuz görüşler de bulunmaktadır. Uzaktan eğitimde uygulama ve materyallerin sınırlı kalmasından dolayı konuşma ve yazma becerilerinin geliştirilememesi (Güngör vd., 2020; İskender, 2021); ödev kontrolünde sorun yaşanması (Güngör, 2020); dilbilgisi öğretiminde sorun yaşanması (İskender, 2021); internet ve teknolojik araçlarda sorun yaşanması (Güngör vd., 2020; İskender, 2021; Ustabulut, 2021); çevrimiçi sınıf ortamına uyumda zorlanma (İskender, 2021; Özer ve Çekici, 2020; Ustabulut, 2021) beden dili kullanımının sınırlı kalmasından kaynaklanan iletişim sorunlarının olması (Alibekiroğlu, 2021), derslere etkin katılım ve devam sorunlarının bulunması (Özer ve Çekici,2020) gibi sonuçlara ulaşılmıştır. Bu çalışmada var olan çalışma sonuçlarına benzer olarak,

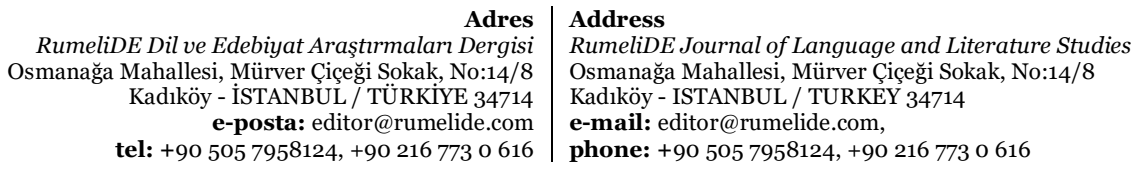


konuşma ve yazma becerilerinin geliştirilememesi sorunu, internet ve teknolojik araçlardan kaynaklanan sorunlar, iletişim sorunları, derslere etkin katılım ve devam sorunları olduğu belirlenmiştir.

Üretici dil becerileri konuşma ve yazmanın yeteri kadar gelişmemesine, uzaktan eğitimde isteksiz öğrencilerin derse etkin katılmamaları, bu yüzden de onları derslerde konuşturmanın, sesletim sorunlarını düzeltmenin ve yazma çalışmalarına anında dönüt vermenin zor olması neden olarak gösterilebilir. İnternet ve teknolojik araçların kullanımından kaynaklanan sorunlar da öğrencilerin kullandıkları internet paketlerinin yeterli kotaya sahip olmaması, elektrik kesintileri ya da kullanılan teknolojik araçların niteliğinin uzun süreli eğitime elverişli olmamasından kaynaklanmaktadır. Ayrıca teknolojik araçlar, uygulamalar ve uzaktan eğitim sistemi kimi zaman sorun çıkarabilmektedir. Ders bağlantısının, mikrofonun ya da kameranın çalışmaması, 'derse katıl' butonunun bazen etkin olmaması da derslerde sorun yaşanmasına neden olmaktadır. Derslerde yaşanan bu sorunların yanı sıra sözsüz iletişimin de yeteri kadar kullanılamaması iletişim sorununu beraberinde getirmektedir. Derste arkadaşları ve öğretmeni ile yeterli iletişimi kuramayan öğrenci derse olan ilgisini kaybetmektedir. Bütün bu olumsuzluklar da onların derslere odaklanmalarını engellemektedir. Bunlardan farklı olarak öğrenciler derste yapılan açıklamaların yetersiz olması, derslerin nitelikli olmaması, derslerde sosyalleşme ve işbirlikli öğrenme ortamının olmaması, uzaktan eğitimin sağlı̆̆ olumsuz etkilemesi, pahalı olması ve sınavların güvenilir olmaması gibi olumsuz görüşler de bildirmişlerdir.

Uzaktan eğitim sadece öğrenciler için değil aynı zamanda öğretmenler için de yeni bir öğrenme-öğretme yolu olduğundan öğretmenlerin de buna hazır olması kolay değildir. Bu yüzden yüz yüze eğitimde daha etkin olabilen öğretmenler uzaktan eğitimde anlatmak istediklerini yeterince anlatamayabilmektedirler. Bu durum da öğrencilerin öğretmeni ya anlayamamasına ya da eksik anlamasına; dersleri yeteri kadar anlayamayan öğrencilerin de dersleri nitelikli bulmamalarına neden olabilmektedir. Uzaktan eğitimi nitelikli bulan öğrenci de vardır. Derslerde video, Web araçlarının kullanımı, görsel ve işitsel araçlarla dersi destekleyebilme uzaktan eğitimde daha kolaydır. Yüz yüze eğitimde her sinıfta akıllı tahta olmadığından bu konuda kimi zorluklar yaşanmaktadır. Bu nedenler öğrencilerin, uzaktan eğitimi yüz yüze eğitimden daha nitelikli bulmasına sebep gösterilebilir.

Sosyalleşmede sorun yaşama, uzaktan eğitime getirilen diğer bir eleştiridir. Uzaktan eğitimde sınıf ortamından uzak kalan öğrenciler, arkadaşları ile yüz yüze etkinliklere katılamamaktalar. Bu da onların sosyalleşmelerini engellemektedir. Arkadaşları ile aynı sınıf ortamında bulunmaları sadece sosyalleşmelerini değil aynı zamanda birbirlerinden öğrenebilecekleri işbirlikli öğrenme ortamını da ortadan kaldırmaktadır.

Sürekli bilgisayar, tablet ya da telefon başında olmak, aynı pozisyonda uzun süre durmak çeşitli sağllk sorunlarını da beraberinde getirmektedir. Öğrenciler uzaktan eğitimde sırt ağrısı yaşadıklarını, gözlerinin yorulduğunu ve radyasyona maruz kaldıklarını; kimi öğrenciler ise uzaktan eğitim sayesinde virüsten uzak kalacakları için sağlıklarını koruduklarını belirtmiştir.

Bilgisayar, telefon, tablet ve internet kullanımı sadece sağlıklarını değil ekonomilerini de etkilemektedir. Uzaktan eğitim için yeterli kotaya sahip internet paketi almanın, akıllı telefona, tablete ya da bilgisayara sahip olmanın belirli bir maliyeti vardır. Bu yüzden uzaktan eğitim pahalı olabilir. Bu araçlara erişimi kolay olan öğrenciler için de yol ve yeme içme masraflarını azalttığından uzaktan eğitim yüz yüze eğitime göre daha ucuz olabilmektedir.

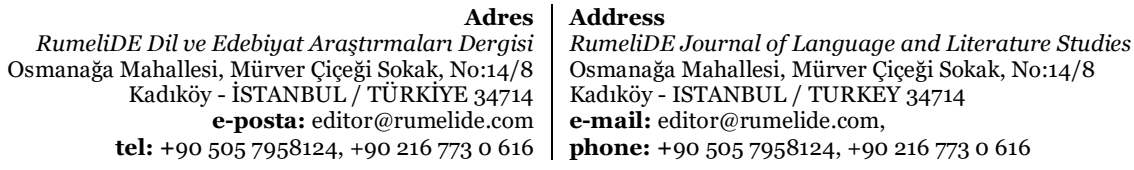


Bu teknolojik araçların kullanımı sadece maliyet değil bazen de sınavlarda kopya çekme açısından sorun olarak karşımıza çıkmaktadır. Sınav esnasında kameranın ya da mikrofonun çalışmaması, kameranın sadece belirli bir alanı görüyor olması, aniden internet ve elektrik kesintisi, sınav esnasında öğrenci takibini zorlaştırmaktadır. Bunlar, öğrencilerin, gerçek başarılarını ortaya koymanın engelleridir.

Sonuç olarak öğrencilerin uzaktan eğitime yönelik görüşleri değerlendirildiğinde öğrenciler her ne kadar olumlu görüş bildirmiş olsalar da yüz yüze eğitimi uzaktan eğitime tercih ettikleri söylenebilir. Türkçenin yabancı dil olarak öğretilmesinde uzaktan eğitimin niteliği artırılabilir, salgın dönemi bitse bile destekleyici bir öğrenme yolu olarak kullanılabilir. Bunun için aşağıdaki önerilerde bulunulabilir:

1. Salgın sonrasında yüz yüze eğitime geçilebildikten sonra, Türkçenin yabancı dil olarak öğretiminde Çetin (2020)'in de önerdiği gibi harmanlanmış öğrenme ortamları sunulabilir. Yüz yüze verilen geleneksel öğrenme ortamları ile çevrimiçi ortamları harmanlayarak daha verimli ve etkili öğrenme ortamları sunulabilir (Başer, 2020). Böylelikle, öğrencilerin uzaktan eğitime yönelik belirttikleri olumlu yanlardan faydalanılmış, olumsuz olduğu düşünülen kısımlarda da yüz yüze eğitimin olanakları kullanılmış olur.

2. Uzaktan eğitimde daha etkili bir iletişim kurabilmek için İnal ve Arslanbaş (2021)'ın da önerdiği gibi iletişim odaklı Web 2.0 araçları (örn. Padlet, Lyrics Training vb.) kullanılabilir. Öğretmenlerin, bu uygulamalar hakkındaki yeterlikleri geliştirilebilir.

3. Uzaktan öğrenmeleri değerlendirmede sadece çevrimiçi sınavlar yerine hem sürecin hem de sonucun değerlendirildiği yöntemler kullanılabilir. Böylece öğrencilerin sadece sınavlarının değil ders sürecindeki katılımlarının da değerlendirileceğini bilmeleri derse etkin katılımı artırabilir. Türkçenin yabancı dil olarak öğretiminde kullanılabilecek Web 2.0 araçları (örn. Kahoot, Nearpod vb.) süreç değerlendirme için çok çeşitli olanaklar sunmaktadır (Sarı̈̈̈l, 2021).

4. Derslerin uzaktan eğitim yoluyla da daha nitelikli işlenebilmesi için öğreticilerin de uzaktan eğitim alanında eğitilmesi çevrimiçi ortamlara uyum sağlayabiliyor olması gerekmektedir. Çetin (2020)'in önerdiği öğretici eğitimleri de harmanlanmış eğitim ortamları aracılığıyla verildiğinde ve bu eğitimlere çevrimiçi ortamlarda verimliliği artıracak araç kullanımları da eklendiğinde bu sorun ortadan kalkacaktır.

\section{Kaynaklar}

Alibekiroğlu, S. (2021). Negative effects of the COVID-19 pandemic on teaching Turkish as a foreign language. GS Skovoroda Kharkiv Ulusal Pedagoji Üniversitesi. http://dspace.hnpu.edu.ua/handle/123456789/5287

Baser, D. Harmanlanmış öğrenme ortamları. E. Tekinarslan \& M. D. Gürer (Ed.), Açık ve Uzaktan Öğrenme (ss. 125-144). Ankara: Pegem Akademi. https://doi.org/10.14527/9786052412411.07

Çetin, O. (2020). Yabancılara Türkçe öğretimi sertifika programlarında görülen eksiklikler ve çözüm önerileri. XV. Uluslararası Büyük Türk Dili Kurultayı Bildiri Kitabı (ss.366-375), Gürcistan-Tiflis.

Güngör, H., Çangal, Ö. \& Demir, T. (2020). Türkçe'nin yabancı dil olarak uzaktan öğretimine ilişkin öğrenici ve öğretici görüssleri. Gazi Üniversitesi Gazi Eğitim Fakültesi Dergisi, 4O(3), 1163-1191. https://doi.org/10.17152/gefad.756612

Gürer, M. D. (2021). Açık ve uzaktan öğrenmenin temelleri. E. Tekinarslan \& M. D. Gürer (Ed.), Açık ve Uzaktan Öğrenme (ss. 1-28). Pegem Akademi. https://doi.org/10.14527/9786052412411.07

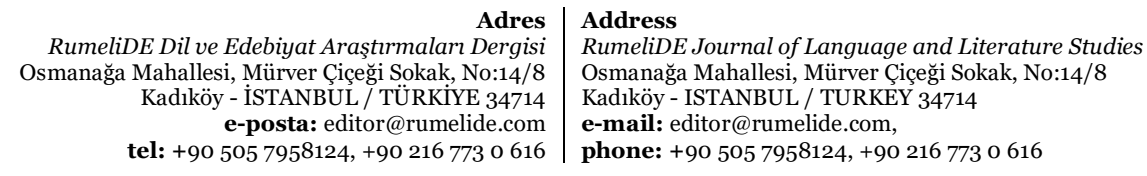


İnal, E. \& Arslanbaş, F. (2021). Türkçenin yabancı dil olarak uzaktan öğretiminde iletişim odaklı Web 2.0 araçları ve uygulama örnekleri. Bayburt Eğitim Fakültesi Dergisi, 16(Özel Sayı), 228-249. https://doi.org/10.35675/befdergi.850781

İskender, M. E. (2021). Yabancı dil olarak Türkçe öğretiminde uzaktan eğitim derslerine ilişkin deneyimler. RumeliDE Dil ve Edebiyat Araşttrmaları Dergisi, 22, 96-117. https://doi.org/10.29000/rumelide.885523

Özer, Ö. \& Çekici, Y. E. (2020). Uzaktan eğitim yoluyla yürütülen Türk dili derslerinin değerlendirilmesi: Nitel bir araştırma. RumeliDE Dil ve Edebiyat Araştırmaları Dergisi, Ö7, 92- 110. https://doi.org/10.2900o/rumelide.808251

Sadeghi, M. (2019). A shift from classroom to distance learning: Advantages and limitations. International Journal of Research in English Education, 4(1), 80-88. https://doi.org/10.29252/ijree.4.1.80

Sarıgül, K. (2021). Yabancı dil olarak Türkçe öğretiminde çevrim içi süreç değerlendirme araçları. Karamanoğlu Mehmetbey Üniversitesi Edebiyat Fakültesi Dergisi, 4(Yunus Emre ve Türkçe Yılı Yabancı Dil Olarak Türkçe Öğretimi Özel Sayısı), 56-80. https://doi.org/10.47948/efad.922748

Schlosser, L. A., \& Simonson, M. (2009). Distance education: Definition and glossary of terms (3rd ed.). Charlotte, NC: Information Age.

Ustabulut, M.Y. (2021). SWOT analysis for the distance education process of lecturers teaching Turkish as a foreign language. Educational Policy Analysis and Strategic Research, 16(1), 139-152. https://doi.org/10.29329/epasr.2020.334.8

Yurtdışı Türkler ve Akraba Topluluklar Başkanlı̆̆ (2021, August o3). Uluslararası Öğrenci Hareketliliği. https://www.ytb.gov.tr/uluslararasi-ogrenciler/uluslararasi-ogrenci-hareketliligi

RumeliDE Dil ve Edebiyat Araşturmaları Dergisi Osmanağa Mahallesi, Mürver Çiçeği Sokak, No:14/8 Kadıköy - İSTANBUL / TÜRKIYE 34714 e-posta: editor@rumelide.com tel: +90 $5057958124,+902167730616$
Address

RumeliDE Journal of Language and Literature Studies Osmanağa Mahallesi, Mürver Çiçeği Sokak, No:14/8

Kadıköy - ISTANBUL / TURKEY 34714

e-mail: editor@rumelide.com,

phone: +90 $5057958124,+902167730616$ 